\title{
Production and Characterization Package of Reference and Advanced Feedstock
}

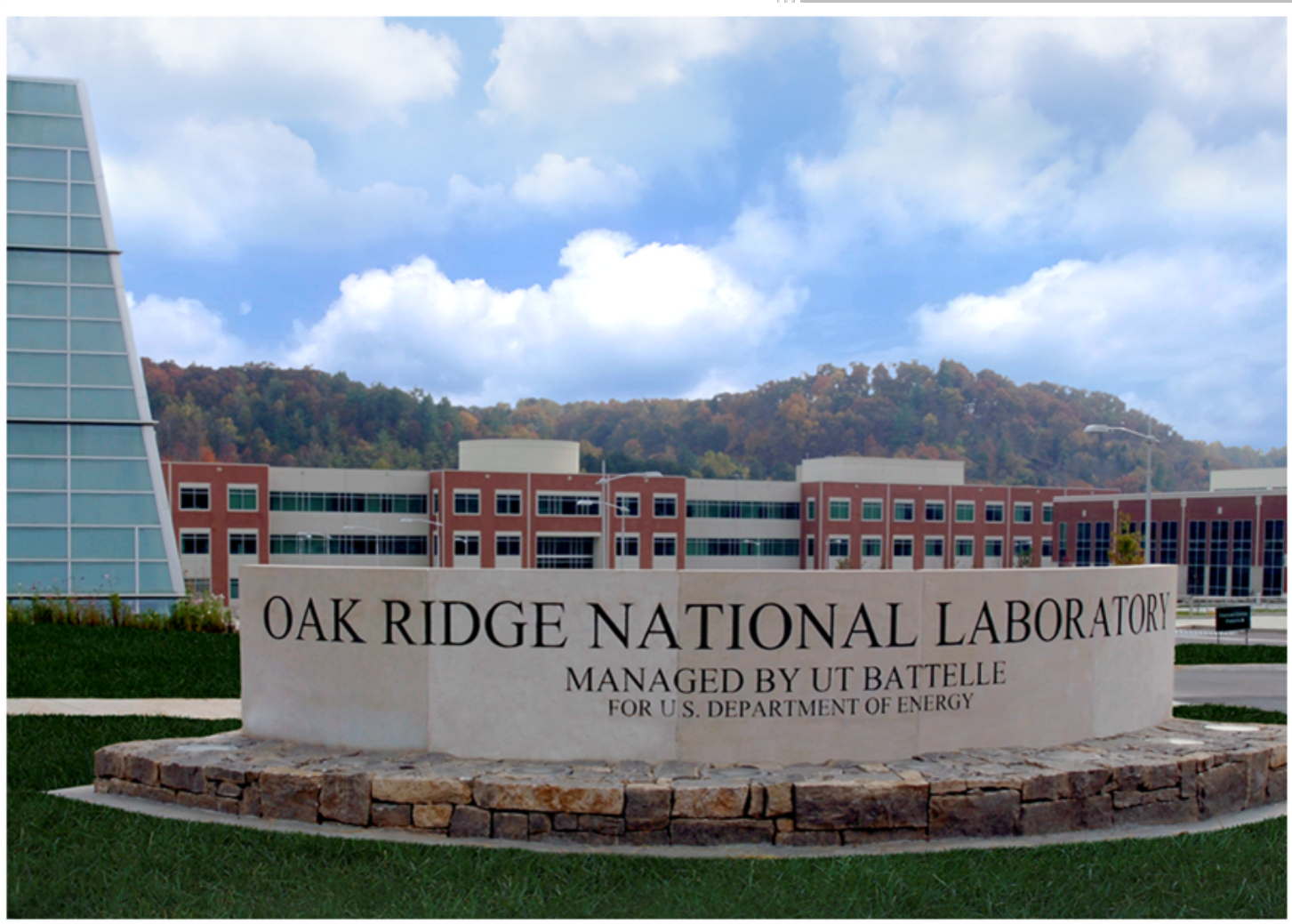

\section{Approved for public release.} Distribution is not limited.

Alicia M. Raftery

June 2019 


\title{
DOCUMENT AVAILABILITY
}

Reports produced after January 1, 1996, are generally available free via US Department of Energy (DOE) SciTech Connect.

Website www.osti.gov

Reports produced before January 1, 1996, may be purchased by members of the public from the following source:

\author{
National Technical Information Service \\ 5285 Port Royal Road \\ Springfield, VA 22161 \\ Telephone 703-605-6000 (1-800-553-6847) \\ TDD 703-487-4639 \\ Fax 703-605-6900 \\ E-mail info@ntis.gov \\ Website http://classic.ntis.gov/
}

Reports are available to DOE employees, DOE contractors, Energy Technology Data Exchange representatives, and International Nuclear Information System representatives from the following source:

Office of Scientific and Technical Information

PO Box 62

Oak Ridge, TN 37831

Telephone 865-576-8401

Fax 865-576-5728

E-mail reports@osti.gov

Website http://www.osti.gov/contact.html

This report was prepared as an account of work sponsored by an agency of the United States Government. Neither the United States Government nor any agency thereof, nor any of their employees, makes any warranty, express or implied, or assumes any legal liability or responsibility for the accuracy, completeness, or usefulness of any information, apparatus, product, or process disclosed, or represents that its use would not infringe privately owned rights. Reference herein to any specific commercial product, process, or service by trade name, trademark, manufacturer, or otherwise, does not necessarily constitute or imply its endorsement, recommendation, or favoring by the United States Government or any agency thereof. The views and opinions of authors expressed herein do not necessarily state or reflect those of the United States Government or any agency thereof. 
Transformational Challenge Reactor Program

\title{
Production and Characterization Package of Reference and Advanced Feedstock
}

\author{
Alicia M. Raftery
}

Date Published: June 2019

Milestone M2CT-19OR06090129

Prepared by

OAK RIDGE NATIONAL LABORATORY

Oak Ridge, TN 37831-6283

managed by

UT-BATTELLE, LLC

for the

US DEPARTMENT OF ENERGY

under contract DE-AC05-00OR2272 


\section{EXECUTIVE SUMMARY}

This milestone report summarizes the synthesis routes used to produce ceramic nuclear fuel feedstock at Oak Ridge National Laboratory (ORNL). The solution-gelation process is used to fabricate microspheres, which are then converted to ceramic fuel materials using various processing conditions. Resulting fuel materials include uranium dioxide $\left(\mathrm{UO}_{2}\right)$, uranium monocarbide (UC), and uranium mononitride (UN). The microsphere size distribution, density, and composition of the fuels can be altered using the conversion routes defined in this report. The resulting materials can be used as the feedstock in a number of additive manufacturing (AM) processes. The present materials were prepared using depleted or natural uranium to facilitate exploratory development activities. However, the laboratories used for this work are authorized for enriched uranium and are actively utilized for this purpose to fabricate fuel test articles for irradiation. If desired, the techniques demonstrated in this document can be readily used for enriched material production to support the Transformational Challenge Reactor (TCR) program. 


\section{TABLE OF CONTENTS}

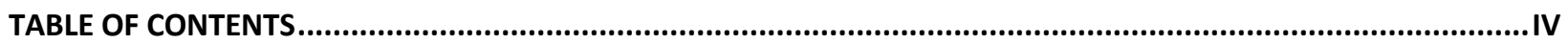

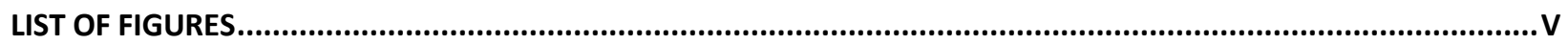

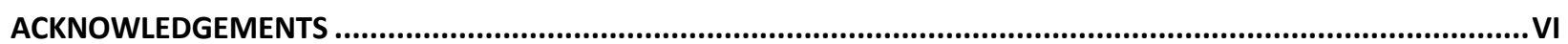

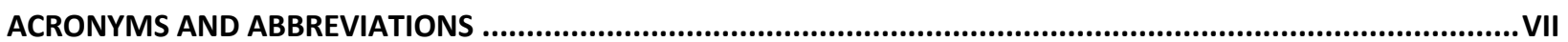

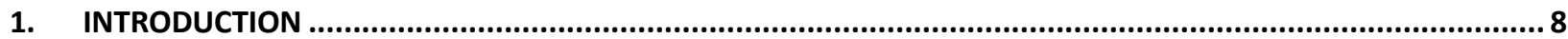

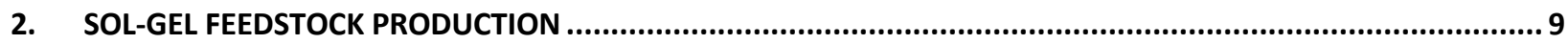

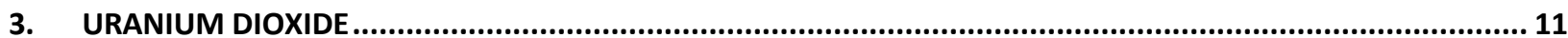

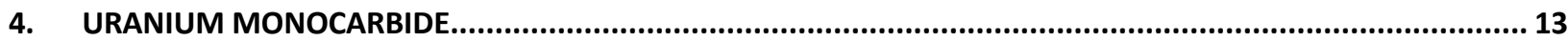

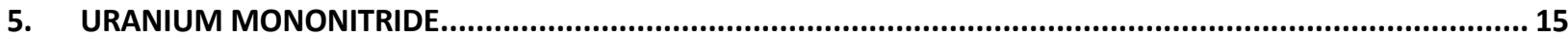

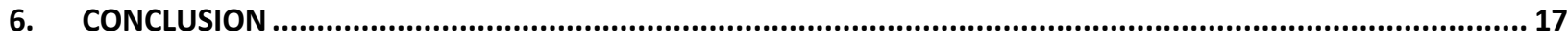

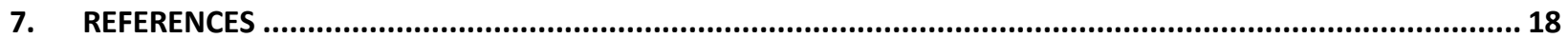




\section{LIST OF FIGURES}

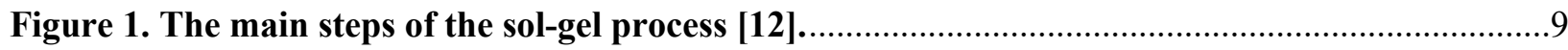

Figure 2. Internal gelation system with major components labeled [14].......................................10

Figure 3. Air-dried yellow $\mathrm{UO}_{3} \cdot \mathrm{H}_{2} \mathrm{O}$ microspheres [12]........................................................... 10

Figure 4. Representative temperature profile for calcination of $\mathrm{UO}_{3}$ microspheres to $\mathrm{UO}_{2}$ in a reducing environment [19].

Figure 5. XRD pattern (plot) of as-calcined 200-240 $\mu \mathrm{m} \mathrm{UO}_{2}$ microspheres showing the peak locations for the precluding uranium oxide phases and optical image (upper right) of spheres.

Figure 6. Representative temperature profile for conversion of $\mathrm{UO}_{3}+\mathrm{C}$ to $\mathrm{UC}[22] \ldots \ldots \ldots \ldots \ldots \ldots \ldots . . . . . . \ldots \ldots$

Figure 7. XRD pattern (plot) and optical image (upper right) for $425 \mu \mathrm{m}$ uranium monocarbide spheres that were fabricated using the temperature profile shown in Figure 6.

Figure 8. Temperature profile and corresponding conversion steps during synthesis of UN [30].

Figure 9. XRD pattern (plot) of $\sim 810 \mu \mathrm{m}$ UN kernels, showing the silicon standard peaks used for lattice parameter analysis and optical image (upper right) of the microspheres.

Figure 10. SEM image of the surface (left) and cross-section (right) for a HIPed uranium nitride kernel. 


\section{ACKNOWLEDGEMENTS}

The author would like to acknowledge the technical contributions of Rodney Hunt, Sarah Finkeldei, and Jake McMurray, all of whom had roles in developing the work summarized in this report. 


\section{ACRONYMS AND ABBREVIATIONS}

$\begin{array}{ll}\text { ADUN } & \text { acid-deficit uranyl nitrate } \\ \text { AGR } & \text { Advanced Gas Reactor } \\ \text { AM } & \text { additive manufacturing } \\ \text { HIP } & \text { hot-isostatic pressing } \\ \text { KEMA } & \text { Keuring van Elektrotechnische Materialen te Arnhem } \\ \text { ORNL } & \text { Oak Ridge National Laboratory } \\ \text { Sol-gel } & \text { solution-gelation } \\ \text { SEM } & \text { scanning electron microscope } \\ \text { TD } & \text { theoretical density } \\ \text { TRISO }_{\text {UC }} & \text { tri-structural isotropic } \\ \mathrm{UF}_{6} & \text { uranium monocarbide } \\ \mathrm{UHP} & \text { uranium hexaflouride } \\ \mathrm{UN} & \text { ultra-high purity } \\ \mathrm{UO}_{2} & \text { uranium mononitride } \\ \text { uranium dioxide } & \text { uranium trioxide } \\ & \text { x-ray diffraction } \\ & \end{array}$




\section{INTRODUCTION}

The conventional method used to fabricate commercial ceramic nuclear fuel consists of powder processing, in which uranium dioxide $\left(\mathrm{UO}_{2}\right)$ powders are cold-pressed and sintered at high temperatures $\left(1700-1800^{\circ} \mathrm{C}\right)$ to form solid cylindrical fuel pellets. Despite the safety requirements for handling of radioactive powders, these fabrication steps are relatively simple to execute on an industrial level. The $\mathrm{UO}_{2}$ powder feedstock is produced in a conversion process, starting with uranium hexafluoride $\left(\mathrm{UF}_{6}\right)$. In addition to powders, alternative feedstock types have been explored, and their feasibility to be used to produce high-density fuel pellets has been demonstrated. For example, microsphere feedstock produced via the solution-gelation (sol-gel) method has been successfully used to fabricate $\mathrm{UO}_{2}$ fuel pellets using sphere-pac techniques, where smear densities as high as $92 \%$ theoretical density (TD) can be attained using three different sphere sizes [1]. The primary motivation behind using an alternative feedstock and fabrication process was twofold: chemistry production of feedstock would require less steps than conventional powder processing and the use of microspheres eliminates the radiological hazards associated with dust creation [2].

Various additive manufacturing (AM) techniques are being recognized as feasible alternative methods for fabricating materials and are now being used in a number of industries to replace conventional methods, including aerospace and tissue engineering $[3,4]$. Techniques that have been demonstrated with at least some success on ceramics include binder jetting [5], material extrusion [6], powder bed fusion [7], material jetting [8], and vat photopolymerization (stereolithography) [9]. Based on these successes, these techniques are also under consideration as viable methods to produce ceramic nuclear fuels.

The Transformation Challenge Reactor (TCR) program at Oak Ridge National Laboratory (ORNL) has the goal of building an additively manufactured microreactor, thereby analyzing the most current AM technology for the nuclear industry, including nuclear fuel fabrication. The benefits of using AM to fabricate nuclear fuels range from geometrical considerations to material-specific advantages [10]. In addition, the potential for incorporating elements for in-situ monitoring during the build process can be advantageous for fulfilling regulatory requirements on material quality assurance.

Each AM technique requires a specific feedstock type, ranging from solid to slurry to liquid-based materials. In addition, the desired feedstock properties for each technique differ slightly, depending on the specifics of the AM process. For instance, the main feedstock properties analyzed for the binder jetting process, which uses primarily powder feedstock, are powder flowability, particle size distribution, and tap density of the material. On the contrary, stereolithography uses a feedstock of material dispersed in a liquid photopolymer, so the desired properties are more related to the dispersibility and refractive index of the feedstock material. Uranium-bearing feedstock requirements for AM processes are anticipated to be generally similar to requirements for surrogate materials, except that providing the feedstock will require special radiological facilities that include additional safety and security considerations. Use of certain AM techniques may also pose a greater operational challenge for use with uranium due to either radiological protection or material-at-risk considerations.

This report highlights the feedstock production capabilities at Oak Ridge National Laboratory (ORNL), with the focus on production of feedstock to be used in AM of ceramic nuclear fuels in support of the TCR program. The synthesis processes currently used for various fuel feedstock types (uranium dioxide, uranium nitride, uranium carbide) are outlined and the materials fabricated using each process are characterized. The purpose of this work is to demonstrate that ORNL is strategically equipped to produce ceramic nuclear fuel feedstock for AM processes, and provide initial uranium feedstock materials for the TCR program. 


\section{SOL-GEL FEEDSTOCK PRODUCTION}

The solution-gelation (sol-gel) method of fuel production is a chemistry-based process of mixing liquids that react with one another form gel-like spheres and upon further processing, they become a solid product of fuel microspheres. The internal gelation technique, which is a variation of the sol-gel method, was first used to produce nuclear fuel feedstock at the Keuring van Elektrotechnische Materialen te Arnhem (KEMA) laboratory in the Netherlands and was therefore named the KEMA process [11]. ORNL began using this process to make uranium-bearing microsphere feedstock in the 1970's and has since made significant advancements to the process to improve the feedstock properties; much of this work was performed in support of the Advanced Gas Reactor (AGR) program [12, 13].

The specific steps used in ORNL's internal gelation process at ORNL are outlined in the schematic in Figure 1 and the setup is shown in Figure 2 [14]. A solution of acid-deficient uranyl nitrate is mixed with hexamethylenetetramine-urea to form a broth that is fed into a chilled nozzle. Cold droplets are formed at the nozzle and are released into a heated column of silicon oil, where gelation of uranium trioxide $\left(\mathrm{UO}_{3}\right)$ dihydrate occurs. The droplets are aged in the column for 20 minutes and are then washed and dried, resulting in yellow-colored uranium trioxide $\left(\mathrm{UO}_{3} \cdot \mathrm{H}_{2} \mathrm{O}\right)$ microspheres (Figure 3 ).

One important parameter of the internal gelation process is the method used to dispense the liquid into the gelation column. This dispensation process will define the final geometry and size distribution of the spheres, as well as the production rate. Traditionally, a vibrating spray nozzle was used to dispense the microspheres [15], allowing for a more uniform size distribution. However, the spray nozzle has limitations in terms of minimizing the sphere size. More recently, a two-fluid nozzle method was established that uses static mixers and disperses the drops into a heated 2-ethyl-1-hexanol (2EH) solution. The broth flow rate and the velocity of the $2 \mathrm{EH}$ around the nozzle have an inverse relationship with the size of the resulting spheres [14]. Even though the method enables the production of smaller sphere sizes, the resulting size distribution using the two-fluid nozzle is typically larger compared to that produced using the vibrating nozzle. Regardless of the nozzle type used, a specific range of microsphere sizes can be selected from the resulting batch by sieving or using a roller micrometer.

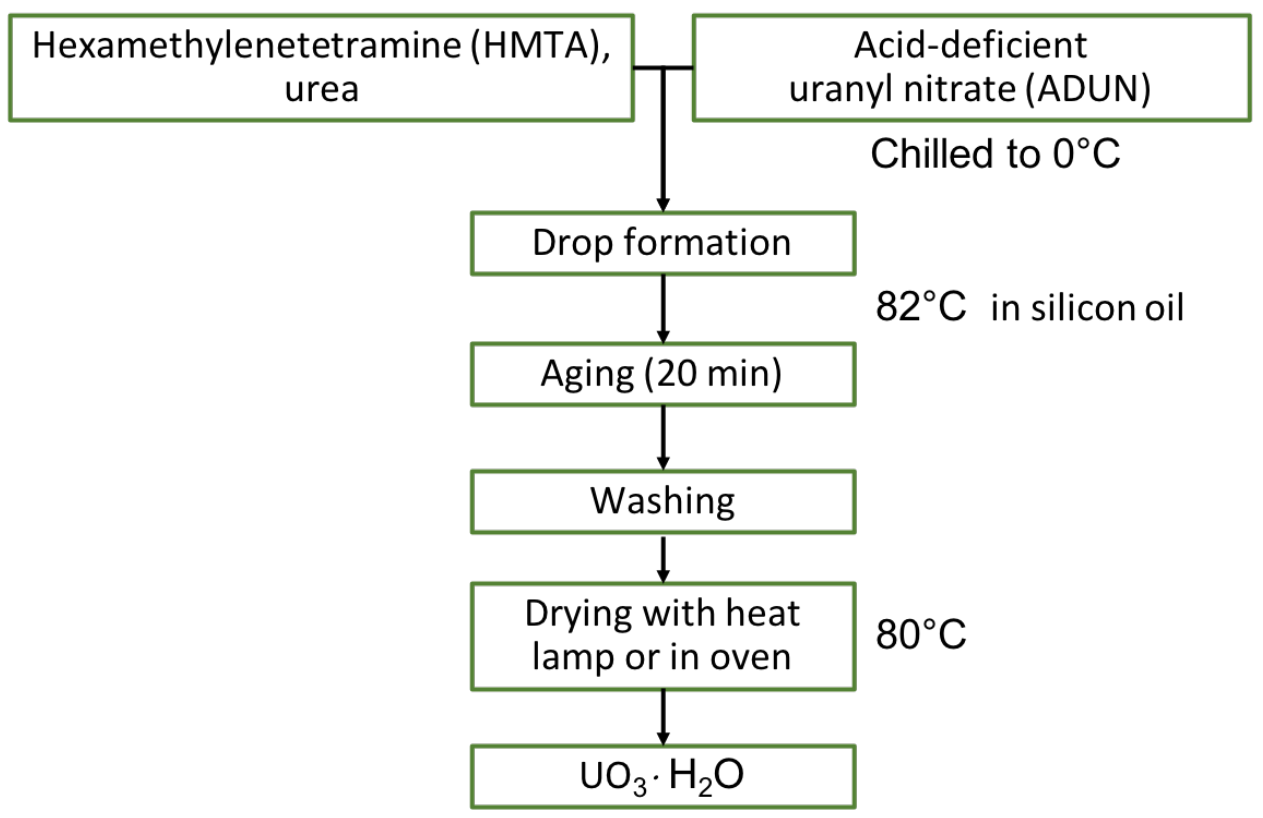

Figure 1. The main steps of the sol-gel process [12]. 


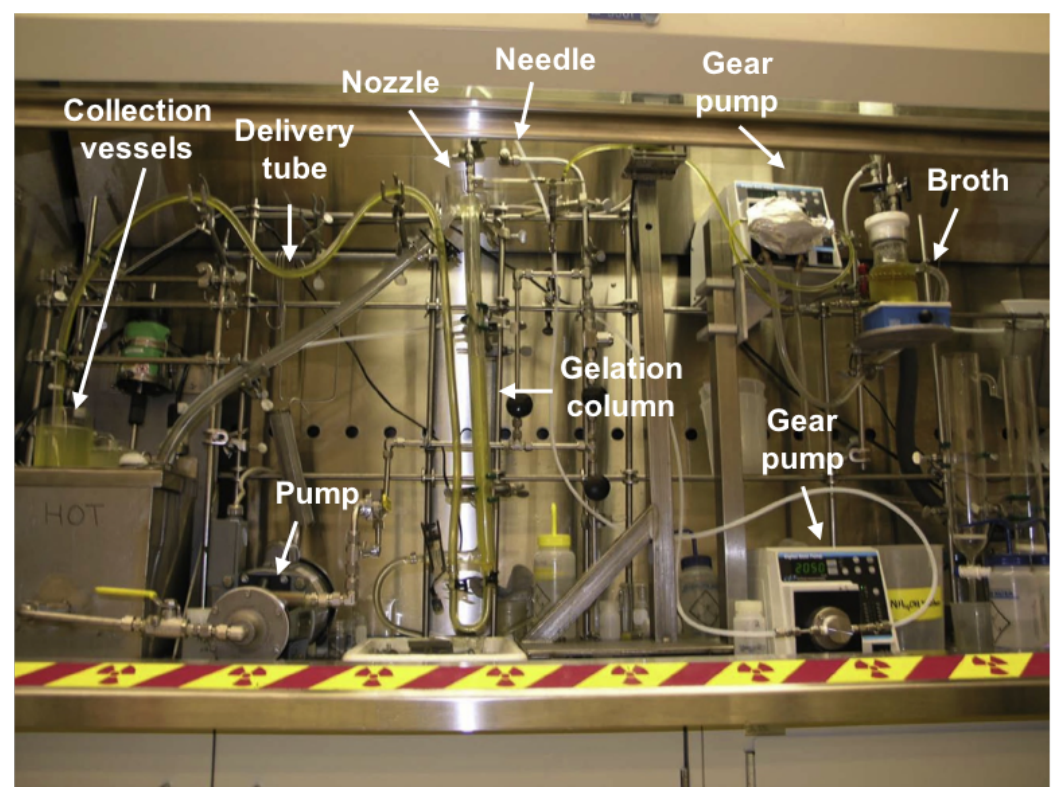

Figure 2. Internal gelation system with major components labeled [14].

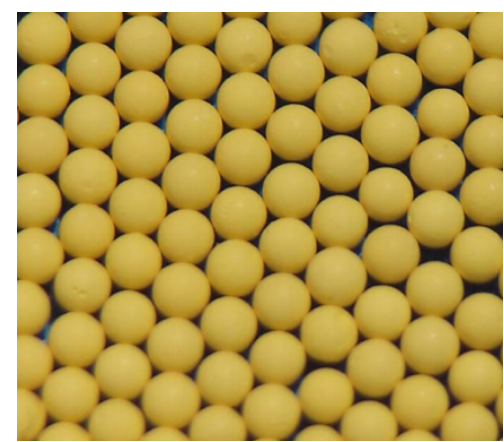

Figure 3. Air-dried yellow $\mathrm{UO}_{3} \cdot \mathrm{H}_{2} \mathrm{O}$ microspheres [12].

In terms of magnitude, the production capability for the vibrating nozzle and two-fluid nozzle sol-gel processes are equivalent. While the current setup can produce a maximum of approximately $80 \mathrm{~g}$ per batch [14-16], outfitting the system to handle a higher batch size should be relatively straightforward and can be accomplished by adapting components to handle more throughput. Additionally, while one gelation line currently only handles 2-3 runs per day, the throughput can be scaled up using multiple lines. Therefore, the method of internal gelation is considered well equipped for industrial-scale fuel production.

One of the most beneficial aspects of the sol-gel process is that the microsphere chemical properties can be tailored to enable fabrication of various fuel materials by altering the broth. Carbon is often added to the broth, since it is required in carbothermic reduction processing of the microspheres during subsequent conversion steps. The amount of carbon added to the broth is defined by the conversion process for which the feedstock is made, which will be detailed further in the following sections of this report. The carbon is mixed in the form of carbon black with Tamol SN dispersant at the desired molar ratio using an ultrasonic probe. The spheres resulting from the internal gelation process are $\mathrm{UO}_{3}$ with carbon dispersed homogenously $\left(\mathrm{UO}_{3}+\mathrm{C}\right)[17]$. ORNL has successfully developed processes for converting these spheres to uranium dioxide, uranium nitride, and uranium carbide, as discussed in the following sections. 


\section{URANIUM DIOXIDE}

$\mathrm{UO}_{3}$ can be converted directly to uranium dioxide in a process typically referred to as calcination. While carbothermic reduction is an option for conversion, there is no need to add carbon to the microspheres, since this reduction reaction will proceed in a reducing atmosphere [18]. Based on prior developmental work at ORNL [19], the heating profile has been optimized to convert the $\mathrm{UO}_{3}$ microspheres to $\mathrm{UO}_{2}$; a typical temperature profile used for calcination is shown in Figure 4. The yellow-colored $\mathrm{UO}_{3}$ spheres are placed in an alumina crucible and heated in a tube furnace to a temperature of at least $600^{\circ} \mathrm{C}$, then they are held for 5 hours in an atmosphere of argon- $4 \%$ hydrogen. The reaction proceeds according to the following equation:

$$
\mathrm{UO}_{3}+\mathrm{H}_{2} \rightarrow \mathrm{UO}_{2}+\mathrm{H}_{2} \mathrm{O}
$$

Two separate reduction steps that occur during the conversion. First $\mathrm{UO}_{3}$ is reduced to $\mathrm{U}_{3} \mathrm{O}_{8}$, and then $\mathrm{U}_{3} \mathrm{O}_{8}$ is reduced to $\mathrm{UO}_{2}$ [20]. The microspheres reduce to approximately one-third of their original size, so the sphere size is actually tailored in the gelation process depending on the desired $\mathrm{UO}_{2}$ microsphere size [14]. It has also been demonstrated that if dopants are added to the broth in the gelation process, then they will survive calcination and will be distributed throughout the $\mathrm{UO}_{2}$ microsphere matrix [21].

The resulting microspheres are porous $\mathrm{UO}_{2}$, which have been characterized via microscopy and x-ray diffraction (XRD). Figure 5 shows an optical image of a set of as-calcined microspheres in the size range of 200-240 $\mu \mathrm{m}$ in diameter. The XRD pattern of the material is also shown, illustrating that the peaks in the calcined material match those for the $\mathrm{UO}_{2}$ phase and do not match those of the precursor oxide phases. These microspheres can be further sintered at increased temperatures $\left(>600^{\circ} \mathrm{C}\right)$ to increase their density, which may be necessary depending on the ultimate use of the feedstock.

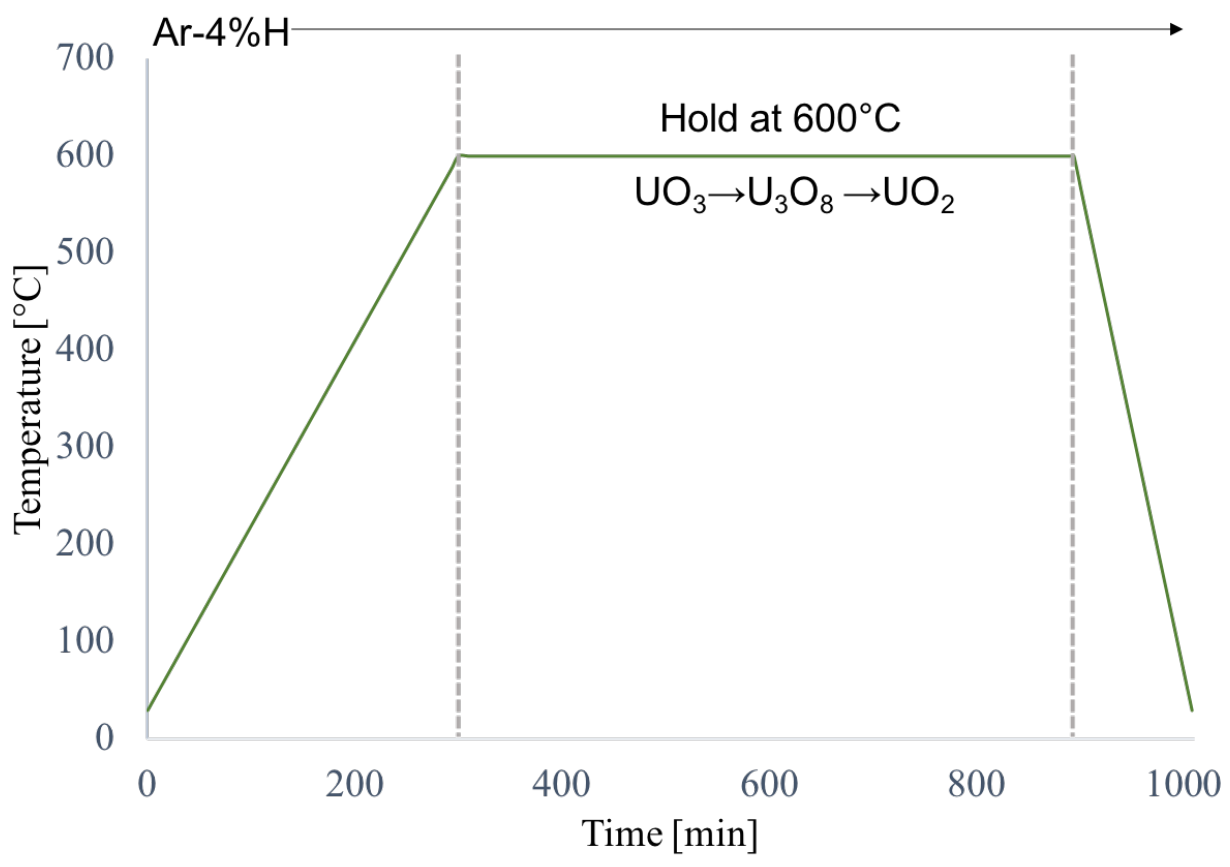

Figure 4. Representative temperature profile for calcination of $\mathrm{UO}_{3}$ microspheres to $\mathrm{UO}_{2}$ in a reducing environment [19]. 


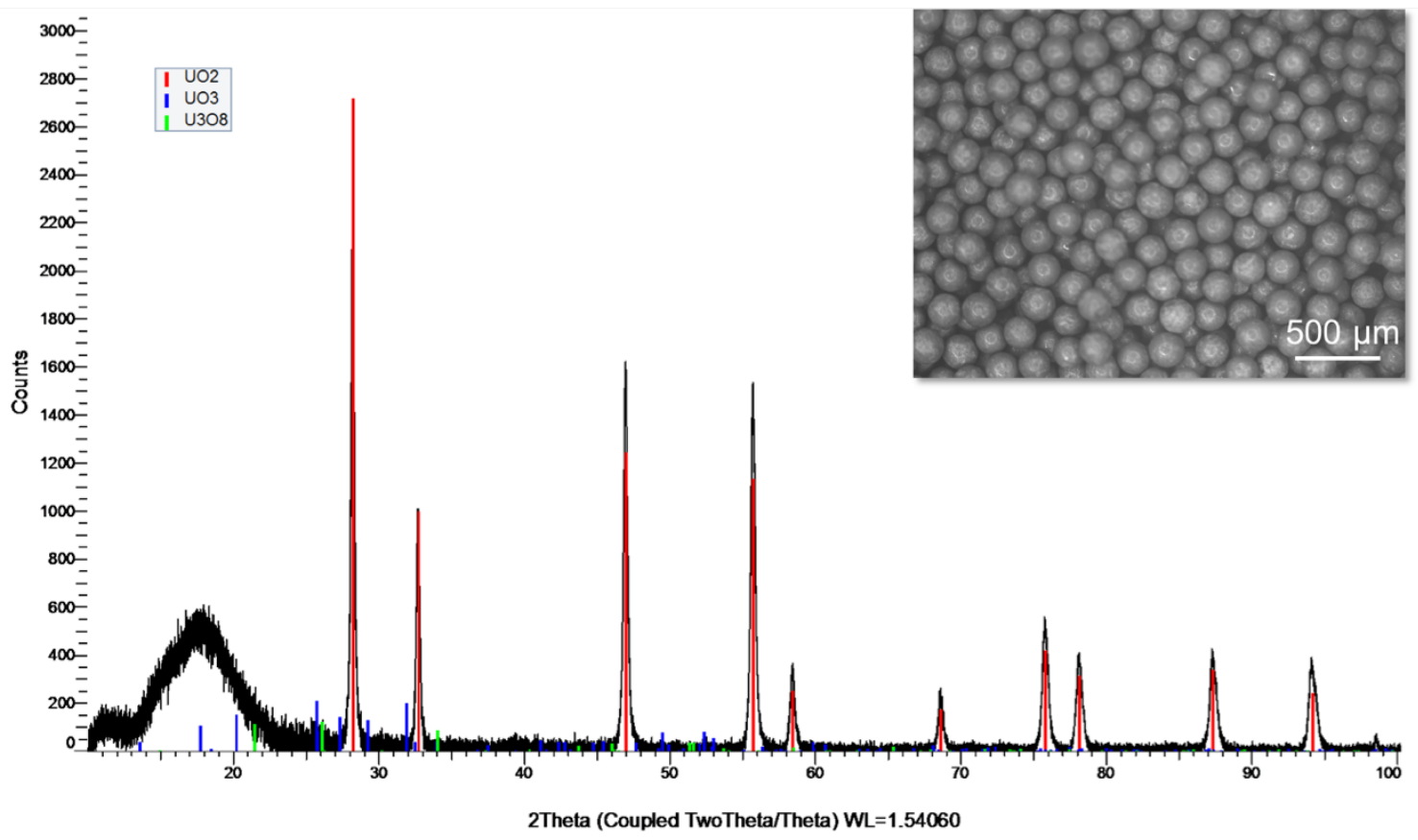

Figure 5. XRD pattern (plot) of as-calcined 200-240 $\mu \mathrm{m} \mathrm{UO}_{2}$ microspheres showing the peak locations for the precluding uranium oxide phases and optical image (upper right) of spheres. 


\section{URANIUM MONOCARBIDE}

$\mathrm{UO}_{3}$ microspheres can be converted to uranium monocarbide (UC) by loading the initial broth with a fixed amount of carbon and subsequently exposing the spheres to certain processing steps to enable carbothermic reduction. The $\mathrm{C} / \mathrm{U}$ ratio should be at least 3.5 to ensure direct carbothermic reduction of the $\mathrm{UO}_{3}$ microspheres before carbide conversion occurs; the first reduction step then proceeds according to the following equation [22]:

$$
\mathrm{UO}_{3}+0.5 \mathrm{C} \rightarrow \mathrm{UO}_{2}+0.5 \mathrm{CO}_{2}
$$

after which the reaction used for carbide conversion is as follows:

$$
\mathrm{UO}_{2}+3 \mathrm{C} \rightarrow \mathrm{UC}+2 \mathrm{CO}
$$

An example of the temperature profile used for the conversion is shown in Figure 6 . The conversion process starts with a transition of $\mathrm{UO}_{3}+\mathrm{C}$ to $\mathrm{UO}_{2}+\mathrm{C}$, a reaction which is completed at around $650^{\circ} \mathrm{C}$ [23]. Afterwards, in the temperature range of $1300^{\circ} \mathrm{C}-1500^{\circ} \mathrm{C}, \mathrm{UO}_{2}+\mathrm{C}$ converts to $\mathrm{UC}$ [24]. The byproduct gases for the carbothermic reduction reactions are $\mathrm{CO}_{2}$ and $\mathrm{CO}$, so safety precautions must be taken to monitor the downstream flow of gas for leaks.

The kinetics for the carbothermic reduction reactions during carbide conversion have shown to be faster under vacuum than argon flow; this is likely due to the faster removal of the byproduct gases with vacuum [24]. However, fast removal of gases and elevated temperature ramps have been found to cause cracking in the spheres during conversion [22]. For this reason, ultra-high purity (UHP) argon flow is used throughout the entire conversion process, and the temperature ramp rates are kept low. An additional sintering step in the form of a 5-hour hold at $1700^{\circ} \mathrm{C}$ has been added to the run profile in Figure 6 in order to further densify the spheres. UC microspheres resulting from these specific processing conditions are shown in Figure 7, along with their resulting XRD pattern, which indicates full conversion to monocarbide.

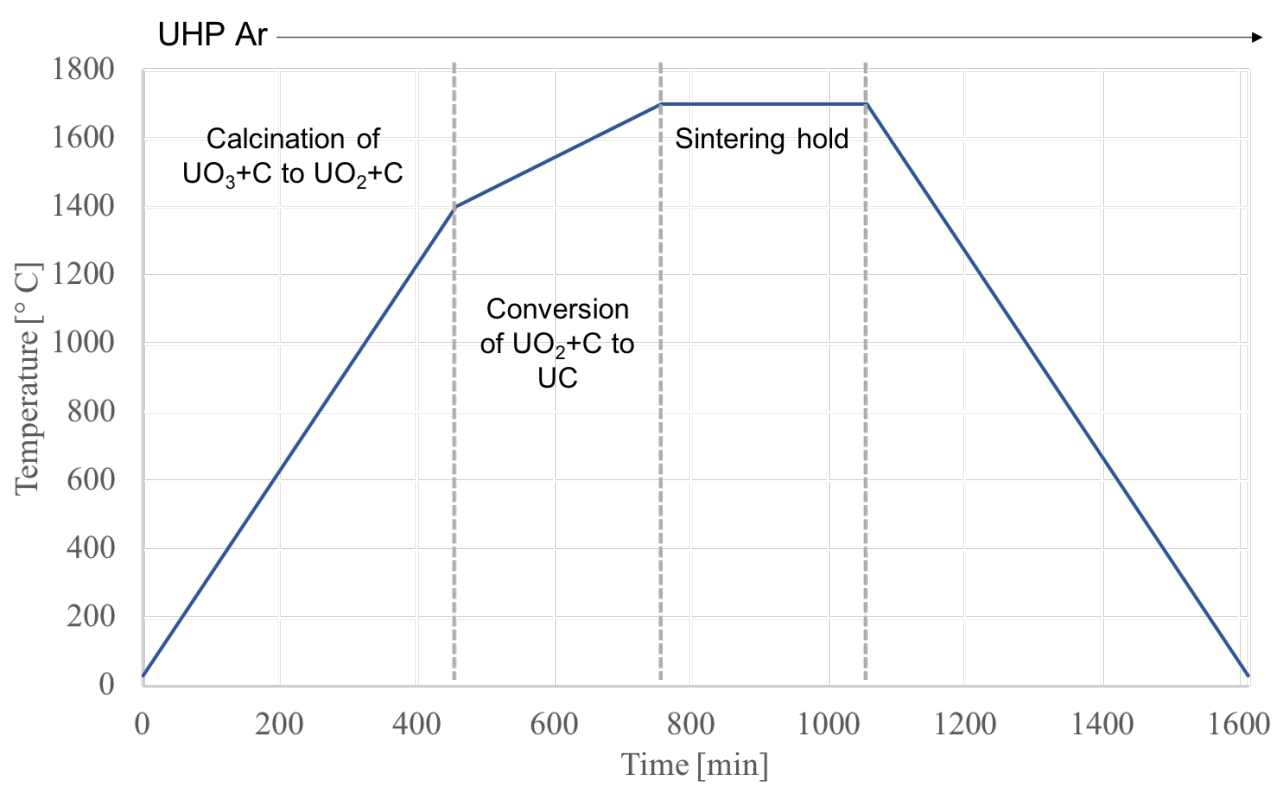

Figure 6. Representative temperature profile for conversion of $\mathrm{UO}_{3}+\mathrm{C}$ to $\mathrm{UC}$ [22]. 


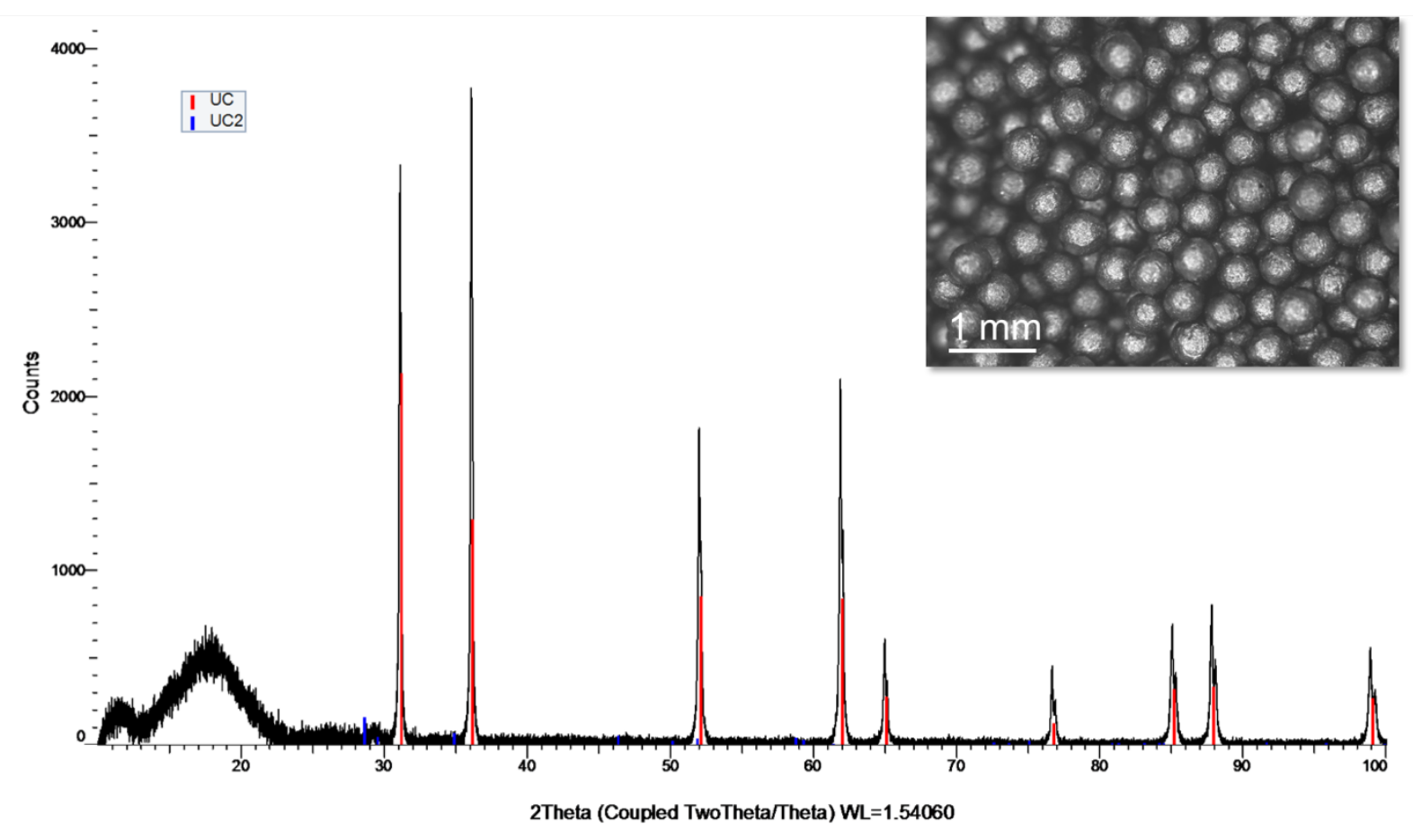

Figure 7. XRD pattern (plot) and optical image (upper right) for $425 \mu \mathrm{m}$ uranium monocarbide spheres that were fabricated using the temperature profile shown in Figure 6.

$\mathrm{UC}$ is a known pyrophoric material, because of its tendency to rapidly oxidize to $\mathrm{U}_{3} \mathrm{O}_{8}$ at atmospheric conditions $[25,26]$. The oxidation reaction rate substantially increases with an increase in temperature and oxygen partial pressure, until an ignition point is reached [27]. The ignition temperature reported for UC in literature ranges from $150^{\circ} \mathrm{C}$ for powder in air $\left(20 \mathrm{kPa} \mathrm{pO}_{2}\right)$ to $217^{\circ} \mathrm{C}$ for $500 \mu \mathrm{m}$ microspheres in an oxygen-rich atmosphere $\left(30 \mathrm{kPa} \mathrm{pO}_{2}\right)$ [27,28]. Material feedstock properties, like whether the monocarbide is in a sphere or powder form, also have an influence on pyrophoricity. Since so many factors must be considered, pyrophoricity is a complicated property to analyze for susceptible materials. These parameters must be considered when analyzing whether the feedstock can be used in certain additive manufacturing techniques. 


\section{URANIUM MONONITRIDE}

The conversion process from $\mathrm{UO}_{3}$ to uranium mononitride (UN) is similar to that for conversion to uranium monocarbide in that in requires an excess of carbon in the $\mathrm{UO}_{3}$ microspheres for carbothermic reduction to occur. The $\mathrm{C} / \mathrm{U}$ ratio, however, is optimized in order to minimize the excess amount of carbon remaining in the spheres after the carbothermic reduction is complete. The $\mathrm{UO}_{3}$ spheres are first calcined according to Eq. (2), and then are reacted with nitrogen according to the following simplified equation:

$$
U \mathrm{O}_{2}+2 \mathrm{C}+0.5 \mathrm{~N}_{2} \rightarrow U N+2 \mathrm{CO}
$$

Typical impurities in the resulting nitride are carbon and oxygen. It was found that in order to minimize the oxygen impurities in the product, an excess of carbon was needed in the reactant [29]. A significant amount of work has been done at ORNL to optimize uranium nitride kernel properties in relation to their use as the fuel kernel in tristructural-isotropic (TRISO) particle fuel [30]. To minimize oxygen impurities in the TRISO nitride kernels, the $\mathrm{C} / \mathrm{U}$ ratio typically used in the sol-gel broth is 2.65 . In addition, a kernel size of approximately $800 \mu \mathrm{m}$ in diameter has been primarily fabricated by using a roller micrometer on the microspheres after conversion. Additional routes of conversion have been used at ORNL to form very high purity nitride for other purposes [31].

The typical temperature profile that is used for converting the carbon-containing $\mathrm{UO}_{3}$ spheres to uranium nitride is shown in Figure 8, and is very similar to the temperature profile used for UC conversion [30]. The major difference is that at $1900^{\circ} \mathrm{C}$, the gas is switched to nitrogen in order to perform a nitriding step, ultimately forming $\mathrm{UC}_{\mathrm{x}} \mathrm{N}_{1-\mathrm{x}}$ as a product. The amount of carbon is analyzed by defining the lattice parameter expansion via the XRD pattern and applying Vegard's law [32]. Figure 9 shows an XRD pattern for a batch of converted uranium nitride kernels. The refined lattice parameter was analyzed from the pattern to be $4.9082 \pm 0.0001 \AA$, meaning that this material has the composition of $\mathrm{UC}_{0.2} \mathrm{~N}_{0.8}$. The carbon content in the product can be further reduced by flowing $\mathrm{N}_{2}-4 \% \mathrm{H}_{2}$ or by using alternate methods of conversion [31,33].

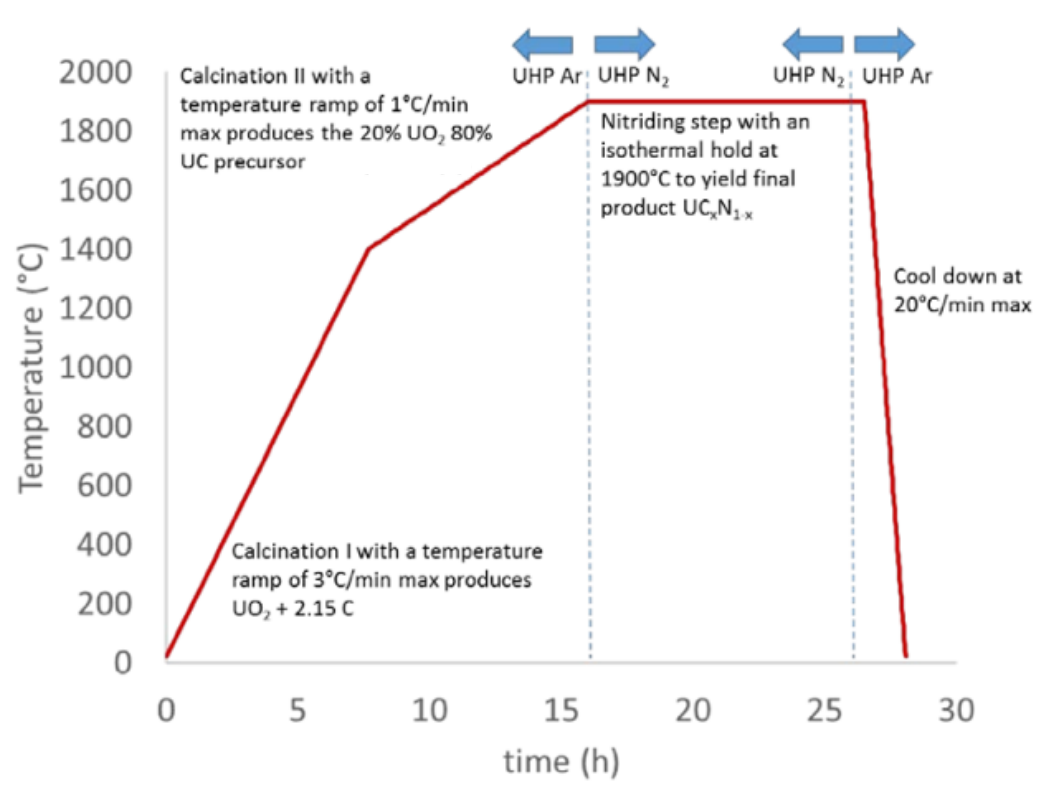

Figure 8. Temperature profile and corresponding conversion steps during synthesis of UN [30]. 


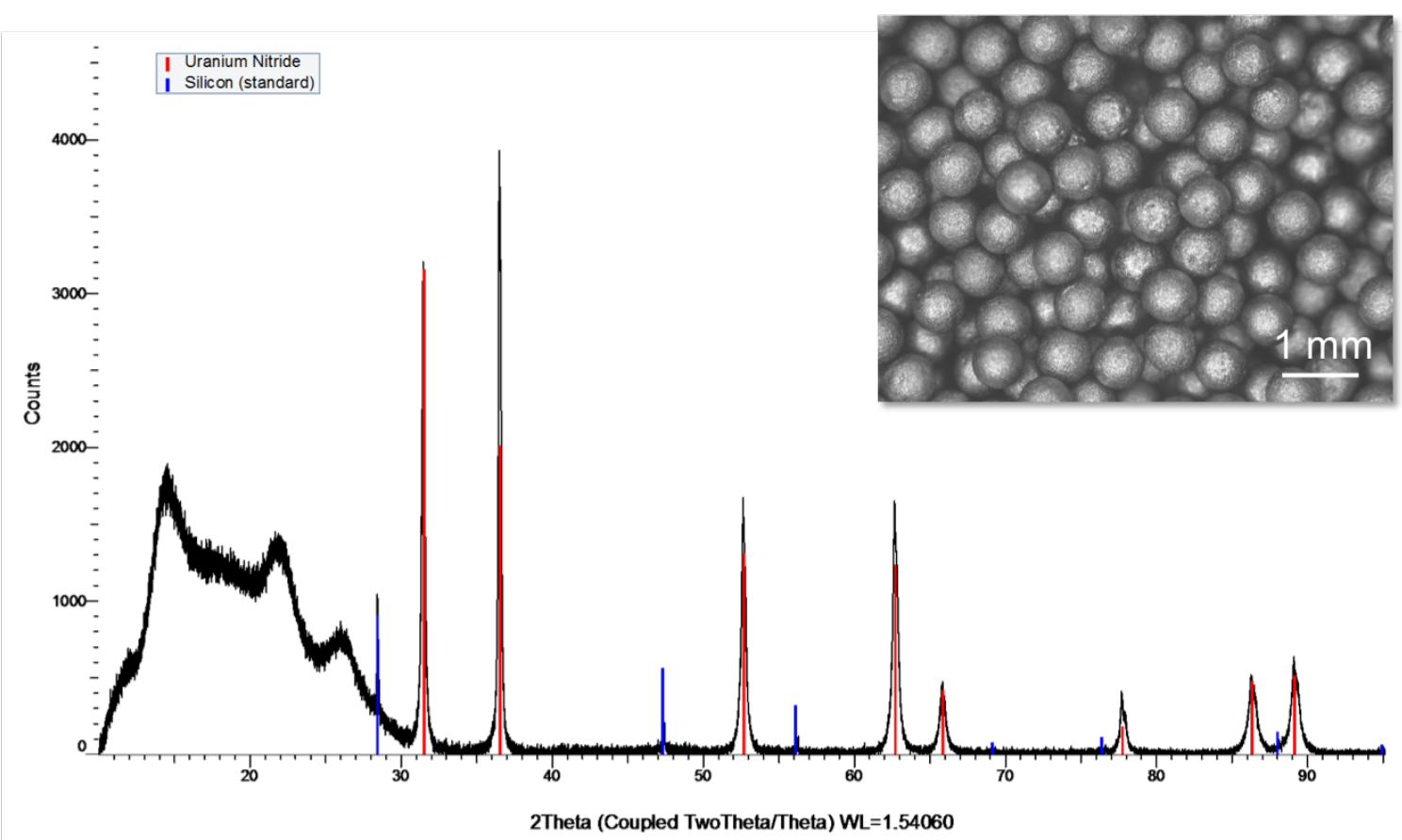

Figure 9. XRD pattern (plot) of $\sim 810 \mu \mathrm{m}$ UN kernels, showing the silicon standard peaks used for lattice parameter analysis and optical image (upper right) of the microspheres.

The density of the kernels can be further increased by using a hot-isostatic press (HIP) processing step. While the density values for as-converted UN microspheres are typically $86-88 \% \mathrm{TD}$ [34], the density can be increased to values up to $97 \%$ TD using the HIP process [34,35]. Figure 10 shows a scanning electron microscope (SEM) image of the surface and microstructure for an $800 \mu \mathrm{m}$ HIPed UN kernel. Similar to the dopants added to $\mathrm{UO}_{2}$, it has been shown that gadolinium can be homogenously added to $\mathrm{UN}$ microspheres via addition to the broth in the sol-gel process, further highlighting the capability of tailored feedstock production [36].
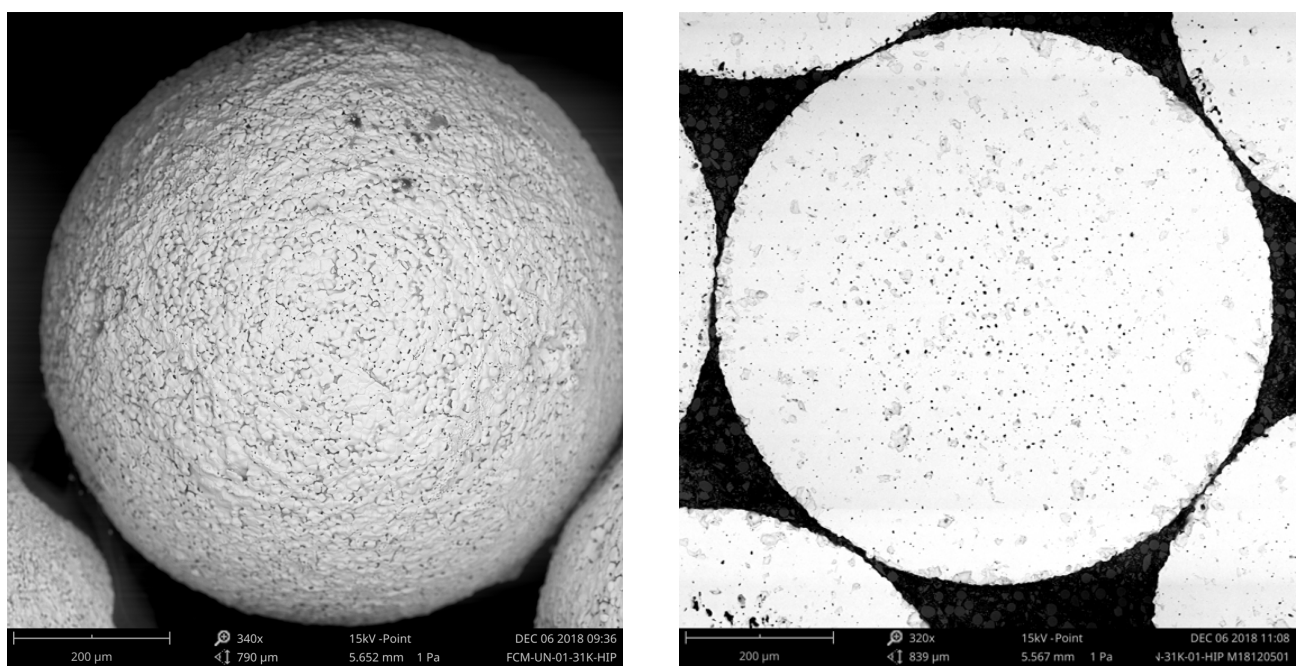

Figure 10. SEM image of the surface (left) and cross-section (right) for a HIPed uranium nitride kernel. 


\section{CONCLUSION}

The nuclear material production requirements of the TCR program can be met using existing resources at ORNL. The presently selected nuclear feedstock materials, $\mathrm{UO}_{2}, \mathrm{UC}$, and $\mathrm{UN}$, have each been prepared at ORNL using reference methods as demonstrated in this report. These are only the primary materials currently fabricated and the opportunity for conversion of additional materials certainly exists. Each feedstock material is initially fabricated into microspheres via internal gelation and then converted to its final form using defined temperature and/or atmospheric conditions. Scaling the internal gelation and the conversion processes to industrial production levels is straightforward, only requiring additional lines of sol-gel processing and larger furnaces for conversion.

The resulting microspheres can be used as feedstock in AM processes, either directly in their microsphere form or converted into a secondary form, such as a slurry or liquid. Feedstock properties can also be tailored depending on the requirements of the AM process, examples include increasing the density or isolating specific sphere sizes. Another benefit of the sol-gel processing route is the ability to add dopants to the feedstock, which results in a homogenous distribution of a secondary phase within the fuel. If dopants are required or if they aid in the function of a specific AM process, this could be an additional processing advantage.

The existing feedstock production capabilities open up a range of opportunities for AM of ceramic nuclear fuels at ORNL. Feedstock fabricated using the routes described in this report will be used to supply research efforts into multiple AM techniques in support of the TCR program. Ultimately, one these methods of fabrication will be selected and used for production of fuel feedstock for the TCR. The present materials were prepared using depleted or natural uranium to facilitate exploratory development activities. However, the laboratories used for this work are authorized for enriched uranium and are actively utilized for this purpose to fabricate fuel test articles for irradiation. If desired, the techniques demonstrated in this document can be readily used for enriched material production to support the TCR program. 


\section{REFERENCES}

1. J. E. Ayer and F. E. Soppet, Nuclear fuel element loading by vibratory compaction-uraniumplutonium carbide specimens for EBR-II irradiation, Argonne National Laboratory, ANL-7076, 1966.

2. K. L. Peddicord, R. W. Stratton, and J. K. Thomas, "Analytical and Experimental Performance of Sphere-pac Nuclear Fuels," Progress in Nuclear Energy 18, 265-299, 1986.

3. S. F. S. Shirazi, S. Gharehkhani, M. Mehrali, H. Yarmand, H. S. C. Metselaar, N. A. Kadri, and N. A. A. Osman, "A review on powder-based additive manufacturing for tissue engineer: selective laser sintering and inkjet 3D printing," Science and Technology of Advanced Materials 16, 033502, 2015.

4. M. Vaezi, S. Chianrabutra, B. Mellor, and S. Yang, "Multiple Material Additive Manufacturing - Part 1: A Review," Virtual and Physical Prototyping 8, 19-50, 2013.

5. P. Kunchala and K. Kappagantula, "3D printing high density ceramics using binder jetting with nanoparticle densifiers," Materials and Design 155, 443-450, 2018.

6. J. A. Lewis, "Direct ink writing of three-dimensional ceramic structures," Journal of the American Ceramic Society 89, 3599-3609, 2006.

7. I. Shishkovsky, I. Yadroitsev, Ph. Bertrand, and I. Smurov, "Alumina-zirconium ceramics synthesis by selective laser sintering/melting," Applied Surface Science 254, 966-970, 2007.

8. K. K. Hon, L. Li and I. M. Hutchings, "Direct writing technology - advances and developments," CIRP Annals - Manufacturing Technology 57, 601-620, 2008.

9. M. Griffith and J. Halloran, "Freeform fabrication of ceramics via stereolithography," Journal of American Ceramic Society 79, 2601-2608, 1996.

10. A. Nelson, "Features that further performance limits of nuclear fuel fabrication: opportunities for additive manufacturing of nuclear fuels," Oak Ridge National Laboratory (forthcoming, 2019).

11. J. B. W. Kanij, A. J. Noothout, and O. Votocik, "The KEMA U(VI) process for the production of $\mathrm{UO}_{2}$ microspheres," Proc., Panel on Sol-gel Processes for Fuel Fabrication, IAEA-161, p. 185, 1974.

12. R. D. Hunt and J. L. Colling, "Uranium kernel formation via internal gelation," Radiochimica Acta 92, 909-915, 2004.

13. R. D. Hunt, F. C. Montgomery, and J. L. Collins, "Treatment techniques to prevent cracking of amorphous microspheres made by the internal gelation process," Journal of Nuclear Materials $\mathbf{4 0 5}$, 160-164, 2010.

14. R. D. Hunt, R. R. Hickman, J. L. Ladd-Lively, K. K. Anderson, R. T. Collins, and J. L. Collins, "Production of small uranium dioxide microspheres for cermet nuclear fuel using the internal gelation process," Annals of Nuclear Energy 69, 139-143, 2014.

15. J. L. Collins, R. D. Hunt, G. D. Del Cul, and D. F. Williams, "Production of depleted $\mathrm{UO}_{2}$ kernels for the Advanced Gas-cooled Reactor program for use in TRISO coating development," ORNL/TM2004/123, Oak Ridge National Laboratory, 2004.

16. R. D. Hunt, J. L. Collins, J. A. Johnson, and B. S. Cowell, "Production of 75-150 $\mu \mathrm{m}$ and $<75 \mu \mathrm{m}$ of cerium dioxide microspheres in high yield and throughput using the internal gelation process," Annals of Nuclear Energy 105, 116-120, 2017.

17. R. D. Hunt, T. B. Lindemer, M. Z. Hu, G. D. Del Cul, and J. L. Collins, "Preparation of spherical, dense uranium fuel kernels with carbon," Radiochimica Acta 95, 225-232, 2007.

18. R. D. Hunt, J. L. Collins, M. H. Lloyd, and S. C. Finkeldei, "Production of more ideal uranium trioxide microspheres for the sol-gel pelletization process without the use of carbon," Journal of Nuclear Materials 515 107-110, 2019.

19. S. C. Finkeldei, J. Kiggans, R. Hunt, K. A. Terrani, and A.T. Nelson, "Fabrication and microstructural analysis of ceramic fuel derived from sol-gel and powder routes," ORNL/SPR2018/866, Oak Ridge National Laboratory (2018).

20. P. O. Alfaro, J. H. Torres, and F. P. Thiele, "Reduction kinetics of uranium trioxide to uranium dioxide using hydrogen," World Journal of Nuclear Science and Technology 5 149-156, 2015. 
21. S. C. Finkeldei, R. D. Hunt, J. O. Kiggans, C. A. Hobbs, B. D. Eckhart, J. W. McMurray, D. R. Brown, G. Helreich, K. A. Terrani, and A. T. Nelson, Oak Ridge National Laboratory, ORNL/SPR2019/1067, 2019.

22. S. K. Mukerjee, J. V. Dehadraya, V. N. Vaidya, and D. D. Sood, "Kinetic study of the carbothermic synthesis of uranium monocarbide microspheres," Journal of Nuclear Materials 172, 37-46, 1990.

23. S. K. Mukerjee, G. A. Rama Rao, J. V. Dehadraya, V. N. Vaidya, V. Venugopal, and D. D. Sood, "Carbothermic reduction of $\left(\mathrm{UO}_{3}+\mathrm{C}\right)$ microspheres to $\left(\mathrm{UO}_{2}+\mathrm{C}\right)$ microspheres," Journal of Nuclear Materials 199 247-257, 1993.

24. S. K. Mukerjee, J. V. Dehadraya, V. N. Vaidya, and D. D. Sood, "Kinetics and mechanism of $\mathrm{UO}_{2}+\mathrm{C}$ reaction for UC/UC 2 preparation," Journal of Nuclear Materials 210, 107-114, 1994.

25. F. Le Guyadec, C. Rado, S. Joffre, S. Coullomb, C. Chatillon, and E. Blanquet, "Thermodynamic and experimental study of UC powders ignition," Journal of Nuclear Materials 393 333-342, 2009.

26. D. Berthinier, C. Rado, O. Dugne, M. Cabie, C. Chatillon, R. Biochot, and E. Blanquet, "Experimental kinetic study of oxidation of uranium monocarbide powders under controlled oxygen partial pressures below 230 ${ }^{\circ}$ C," Journal of Nuclear Materials 432 505-519, 2013.

27. S. K. Mukerjee, G. A. Rama Roa, J. V. Dehadraya, V. N. Vaidya, V. Venugopal, and D. D. Sood, "The oxidation of uranium monocarbide microspheres," Journal of Nuclear Materials 210 97-106, 1994.

28. C. Berthinier, S. Coullomb, C. Rado, E. Blanquet, R. Boichot, and C. Chatillon, "Experimental study of uranium carbide pyrophoricity," Powder Technology 208 312-317, 2011.

29. C. Ganguly, P. V. Hegde and A. K. Sengupta, "Preparation, characterization and out-of-pile property evaluation of (U,Pu)N fuel pellets," Journal of Nuclear Materials 178, 234-241, 1991.

30. J. W. McMurray, C. M. Silva, G. W. Helmreich, T. J. Gerczak, J. A. Dyer, J. L. Collins, R. D. Hunt, T. B. Lindemer, and K. A. Terrani, "Production of low-enriched uranium nitride kernels for TRISO particle irradiation testing," Oak Ridge National Laboratory, ORNL/SR-2016/268, 2016.

31. R. D. Hunt, C. M. Silva, T. B. Lindemer, J. A. Johnson, and J. L. Collins, "Preparation of UC0.070.1N0.90-0.93 spheres for TRISO coated fuel particles," Journal of Nuclear Materials 448, 399-403, 2014.

32. J. Kai, M. Katsura, and T. Sano, "Change of composition of $\mathrm{UC}_{1-\mathrm{x}} \mathrm{N}_{\mathrm{x}}$ in nitrogen gas," Nuclear Science and Technology 5, 43-47, 1968.

33. T. B. Lindemer, C. M. Silva, J. J. Henry, J. W. McMurray, B. C. Jolly, R. D. Hunt, and K. A. Terrani, "Carbothermic synthesis of $820 \mu \mathrm{m}$ UN kernels: investigation of process variables," ORNL/TM2015/301, Oak Ridge National Laboratory, 2015.

34. J. W. McMurray, J. O. Kiggans, and K. A. Terrani, "Examination of HIP for production of high density UN kernels," Oak Ridge National Laboratory, ORNL/TM-2017/155, 2017.

35. J. W. McMurray, J. O. Kiggans, G. W. Helmreich, and K. A. Terrani, K.A., "Production of near-full density uranium nitride microspheres with a hot isostatic press," Journal of American Ceramic Society 101, 4492-4497, 2018.

36. J. W. McMurray, R. D. Hunt, C. M. Silva, G. W. Helmreich, and R. L. Seibert, "Production of UN kernels with Gd additive as burnable absorber," Oak Ridge National Laboratory, ORNL/SPR2018/27, 2018. 